\title{
TMEM173 variants and potential importance to human biology and disease
}

\author{
Seema Patel ${ }^{1} \cdot$ Lei Jin $^{1}{ }^{1}$
}

Received: 24 November 2017 / Revised: 3 January 2018 / Accepted: 5 January 2018 / Published online: 1 May 2018

(c) The Author(s) 2018. This article is published with open access

\begin{abstract}
TMEM173 gene encodes the protein STING (stimulator of interferon genes), a key player in host defense against pathogens. Mutations in the human TMEM173 gene cause a life-threatening auto-inflammatory disease called SAVI (STING-associated vasculopathy with onset in infancy). Human STING is also a promising therapeutic target for cancers and infectious diseases. Recently, Aduro Biotech and Novartis announced a \$250M-plus initiative to develop STING-targeting cancer immunotherapies. Thus, understanding the genetics of the human TMEM173 gene is important for both basic and translational research. The human TMEM173 gene has great heterogeneity and population stratification. R232 of STING is the most common human TMEM173 allele. However, $>50 \%$ of Americans are not R232/R232. HAQ (R71H-G230A-R293Q) is the second most common human TMEM173 allele. While R232/R232 is the dominant TMEM173 genotype in Europeans, R232/HAQ is the most common TMEM173 genotype in East Asians. Importantly, recent studies suggested that $H A Q$ and $H 232$ are likely loss-of-function TMEM173 alleles. In all, $30 \%$ of East Asians and $\sim 10 \%$ of Europeans are $H A Q / H A Q$, $H A Q / H 232$, or $H 232 / H 232$. Here, we reviewed human TMEM173 alleles, mutations and their potential impact on human health and medicine.
\end{abstract}

\section{Introduction}

DNA, including pathogen DNA from infection and mammalian DNA from damaged cells, stimulates STING (stimulator of interferon genes)-dependent type I interferon (IFN) production and promotes inflammation [1, 2]. STING is a four-transmembrane endoplasmic reticulum (ER) resident protein (Fig. 1) [1, 3]. It exists as a homodimer and undergoes a conformational change when binding to its ligands cyclic dinucleotides (CDNs) [3-5]. Activated STING homodimer then traffics through Golgi to the perinuclear region where it activates TANK Binding Kinase 1 (TBK1) leading to type I IFN production [1]. Human transmembrane protein 173 (TMEM173) gene, which encodes the STING protein, is a $\sim 7 \mathrm{~kb}$-long gene at $5 \mathrm{q} 31.2$ (Fig. 1). STING is a critical player in host defense against

Lei Jin

Lei.jin@medicine.ufl.edu

1 Division of Pulmonary, Critical Care and Sleep Medicine, Department of Medicine, University of Florida, Gainesville, FL 32610, USA pathogens, including HIV [6, 7], Plasmodium [8-10], and Mycobacterium tuberculosis [11-13]. STING also influences the development of autoimmune diseases [14, 15]. Last, pharmaceutical companies are developing STINGtargeting immunotherapies [16-18]. The DNA-STING pathway has been reviewed extensively elsewhere [19, 20]. Here, we review the genetics of human TMEM173 alleles, mutations and their potential impact on human health and medicine.

\section{Human population is highly heterogeneous for the TMEM173 gene}

The initial identified human STING has a Histidine at amino acid 232 (H232) [1, 2, 21]. We later found that $H 232$ was a minor allele [22]. The most common TMEM173 allele in the human population has an Arginine at amino acid 232 (R232) [22]. In two cohorts of $\sim 1000$ Americans, $~ 45 \%$ are $R 232 / R 232$, and only $\sim 2 \%$ are $H 232 / H 232$ [22]. Notably, the $H 232$ allele is defective in response to CDNs in vitro [23, 24].

We also found that $>50 \%$ of Americans contain at least one copy of non-R232 TMEM173 allele, which suggested 
Fig. 1 Human TMEM173 gene and its associated diseases. a Cartoon illustrates human TMEM173 gene (NCBI Reference Sequence: NC_000005.10). The common SNPs (R71H, G230A, R232H, and R293Q) are annotated along with the disease-associated SNPs (rs7447927 and rs13181561) identified in the published GWAS [28, 37]. b An annotation of the functional domains in the human STING protein $[3-5,23,75,76]$. TM transmembrane region, $\mathrm{CDN}$ cyclic dinucleotide. Amino acids important for the CDN binding were in black. Common human STING variants were in green. Amino acids important for IRF3 activation were in blue. SAVI mutations were in red. $\mathbf{c}$ The structure of a human STING dimer anchored on the ER membrane [4, 23]. The cytoplasmic tails of the STING dimer form a butterfly-like binding pocket for $\mathrm{CDN}$. The common STING variants G230A and R232H locate on the top (the lid region) of the binding pocket. The R293Q variant locates at the bottom of the pocket. The $\mathrm{R} 71 \mathrm{H}$ variant locates in a predicted cytoplasmic loop facing the bottom of the binding pocket. The SAVI mutations V147M, $\mathrm{N} 154 \mathrm{~S}$ and V155M locate in the stem region of the binding pocket
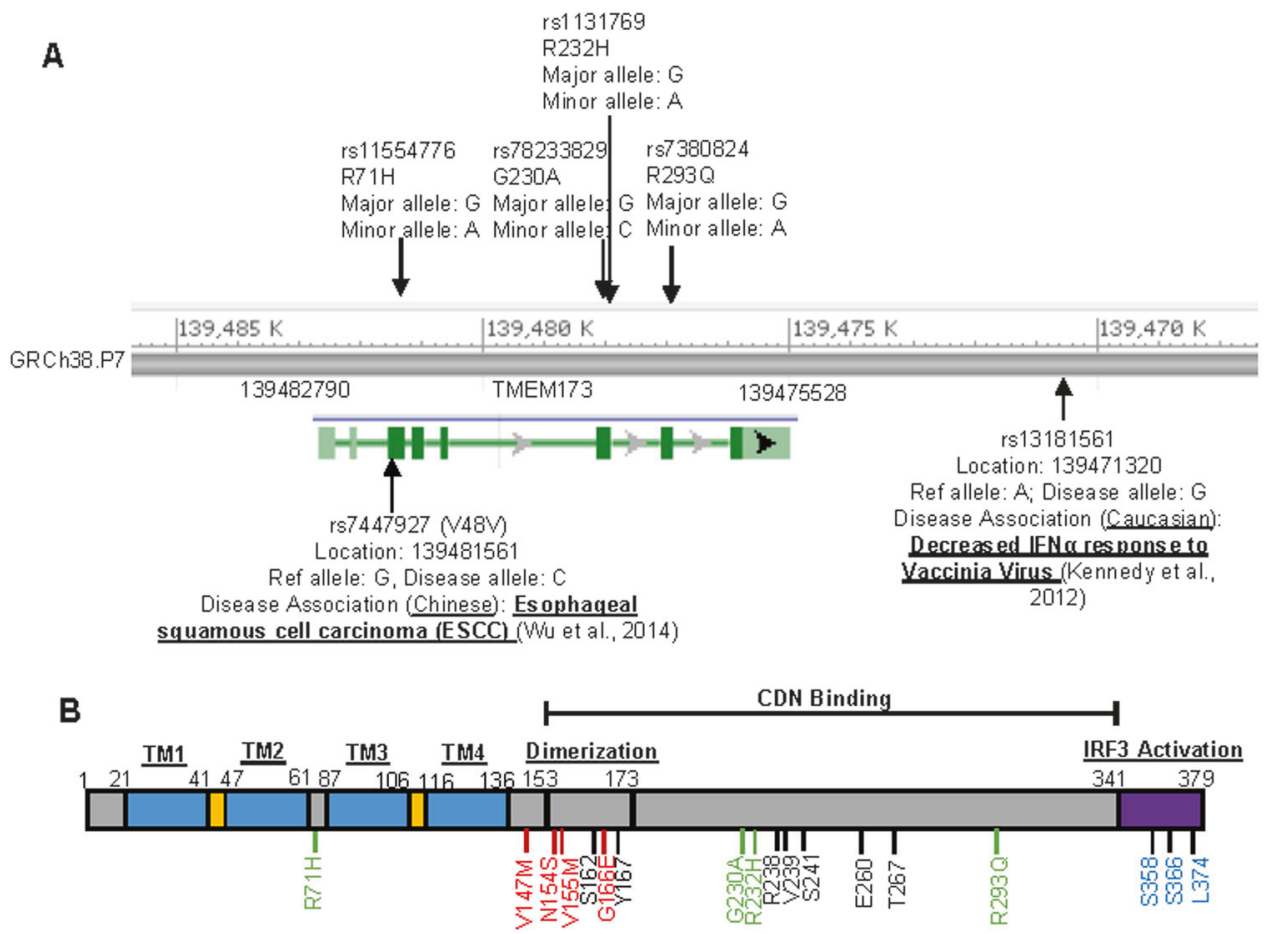

C

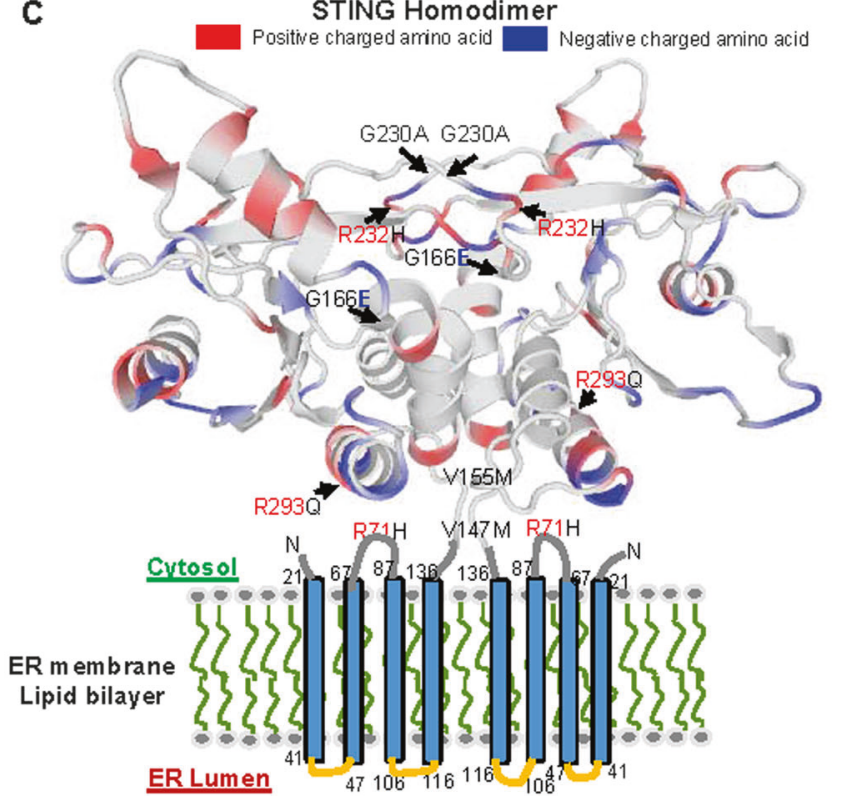

that the human population is highly heterogeneous for the TMEM173 gene [22]. Common TMEM173 alleles $(>1 \%$ population frequency) are $R 232$, HAQ (R71H-G230A$R 293 \underline{Q}$ ), $A Q$ (G230A-R293Q) $Q 293$ and $H 232$ (Fig. 1) [22, 25]. $H A Q$ is the second most common human TMEM173 allele that contains triple non-synonymous single nucleotide polymorphisms (SNPs) (R71ㅍ-G230A-R293Q $)$ [22]. Using B-cell lines derived from homozygous $H A Q / H A Q$ individuals, we recently showed that $H A Q / H A Q$ cells had extremely low STING protein expression and decreased
TMEM173 transcript compared to $R 232 / R 232$ cells [26]. Data from Genotype-Tissue Expression (GTEx) Portal (https://www.gtexportal.org/home/) showed that $H A Q$ individuals had decreased TMEM173 transcript in organs such as artery, skin, lung, and esophagus that are not B-cell dominant [26]. It is likely that $H A Q$ is a null allele [26]. This notion was strengthened in vivo by studies in a knockin $H A Q$ mouse, which did not respond to CDNs [26]. Last, $H A Q$ and $H 232$ alleles are in linkage disequilibrium with rs13181561 that is associated with $>10$-fold decrease of 
IFN $\alpha$ production to vaccinia virus stimulation in Europeans [27, 28]. It is worth noting that Sivick et al. [29] found no functional difference in PBMC among $H A Q$ and $R 232$ individuals although their study had a small sample size with unknown ethnic origins.

The $H A Q$ allele has significant population stratification. In Europeans, $R 232 / R 232$ is the most common genotype, while in East Asian, the dominant genotype is $H A Q / R 232$ [26]. Furthermore, $\sim 16 \%$ of East Asians are $H A Q / H A Q$ compared to $\sim 3 \%$ in Europeans [26]. Interestingly, Africans have no $H A Q / H A Q$ [26]. Instead, $4 \%$ of Africans are $A Q /$ $A Q$, which is absent in other ethnic populations [26]. Africans also have the $Q 293$ allele [26]. It is likely that $Q 293$ is the founder allele, where $A Q$, then $H A Q$, derived during the human migration out of Africa continent.

In summary, the human TMEM173 gene has (i) great heterogeneity; (ii) significant population stratification; (iii) two possible loss-of-function alleles: $H A Q$ and $H 232$. In all, the $H A Q / H A Q, H 232 / H A Q$, and $H 232 / H 232$ genotypes account for $\sim 30 \%$ of East Asians and $\sim 10 \%$ of Europeans [26].

\section{TMEM173 alleles in human health}

STING is essential for host defense against DNA virus and some retroviruses [30]. Considering the vital role of viral infection in human evolution [31], it is surprising that such high percentages of the human population have possible loss-of-function TMEM173 alleles. For example, Herpes simplex virus-1 (HSV-1), a DNA virus, has a high seroprevalence in the human population [32]. When infecting the central nervous system, HSV-1 causes herpes simplex encephalitis, the leading cause of viral encephalitis [33]. The initial study found that STING deficient mice were extremely susceptible to intravenous infection of HSV-1 [34]. So how $H A Q / H A Q, H 232 / H 232$, and $H A Q / H 232$ individuals survived with HSV-1? Two recent studies may shed some light on it. They found that although STING ${ }^{-1-}$ mice were much more susceptible to intravenous HSV-1 infection than the WT mice, there were no difference in survival between the STING ${ }^{-1-}$ and WT mice following a mucosal HSV-1 infection route, which is a natural route of infection in humans [35, 36]. Furthermore, STING was not required for viral clearance and had a minimal effect on type I IFN production during the mucosal HSV-1 infection [35, 36]. Thus, the physiological role of STING in pathogen infection, especially in humans, need to be carefully evaluated.

Genome-wide association study (GWAS) identified two SNPs rs13181561 [28] and rs7447927 [37] within or near the human TMEM173 gene (Fig. 1). In a search for genes associated with cytokine responses to vaccinia virus stimulation, Kennedy et al. [28], linked rs13181561 to decreased IFN $\alpha$ production in European (492 individuals), but not Africans (196 individuals) . rs13181561 is in linkage disequilibrium with $H A Q, H 232$ in Europeans [27], which indicates that these loss-of-function TMEM173 alleles are associated with decreased IFN $\alpha$ production in response to vaccinia virus stimulation in Europeans.

In a joint analysis of three GWAS of esophageal squamous cell carcinoma (ESCC) in Chinese populations (5337 ESCC cases and 5787 controls), Wu et al. [37] found that rs7447927 was associated with ESCC in Chinese populations. rs7447927 is in linkage disequilibrium with rs13181561 [37], which is linked to $H A Q, H 232$ alleles. Thus $H A Q$ and $H 232$ alleles are likely associated with susceptibility to the development of ESCC. It remains to be determined whether the loss of STING function in humans leads to the predisposition to ESCC.

\section{TMEM173 mutations in SAVI (STING- associated vasculopathy with onset in infancy)}

Activating mutations in the TMEM173 gene lead to a newly classified rare auto-inflammatory disease call SAVI [38] (Table 1). It is an autosomal-dominant disease characterized by systemic inflammation, interstitial lung disease, cutaneous vasculitis, and recurrent bacterial infection [38, 39]. Both inherited, and de novo TMEM173 mutations were found in SAVI patients (Table 1). SAVI with the de novo TMEM173 mutations tended to have an early-onset ( $<8$ weeks) and severe phenotype [38, 40], whereas familial TMEM173 mutations had late-onset (teenager or adulthood) and milder clinical manifestations [39, 41]. For instance, SAVI patients with the inherited V155M mutation

Table 1 A summary of identified activating TMEM173 mutations in SAVI patien

\begin{tabular}{llll}
\hline TMEM173-activating mutations in SAVI patients & \\
\hline $\begin{array}{l}\text { Inherited } \\
\text { TMEM173- }\end{array}$ & Affected & De novo & Affected \\
activating & & $\begin{array}{l}\text { TMEM173- } \\
\text { activating } \\
\text { mutations }\end{array}$ & \\
individuals & \\
G166E & & N154S & 4 \\
V155M & 5 & V155M & 5 \\
& 6 & V147M & 2 \\
& & V147L & 1 \\
& & C206Y & 1 \\
& R284G & 1 \\
& R281Q & 1 \\
& S102P-F279L & 1 \\
\hline
\end{tabular}


Table 2 Somatic TMEM173 mutations in primary human cancer tissues

Somatic TMEM173 mutations in cancer subtypes

\begin{tabular}{|c|c|c|c|c|}
\hline Tissue & $\begin{array}{l}\text { Samples with } \\
\text { mutations }\end{array}$ & Tested samples & Mutation & Mutation rate $(\%)$ \\
\hline Skin-face basal cell carcinoma & 1 & 5 & G251E & 20.00 \\
\hline Skin-head neck squamous cell carcinoma & 2 & 39 & S53F, L285I & 5.13 \\
\hline Skin-basal cell carcinoma & 2 & 49 & P92L, [R94C,Y274D $]^{\mathrm{a}}$ & 4.08 \\
\hline Lung-right lower lobe adenocarcinoma & 1 & 45 & $\mathrm{R} 284 \mathrm{M}$ & 2.22 \\
\hline NS-malignant melanoma & 2 & 101 & R232Y, G192S & 1.98 \\
\hline Esophagus-lower third squamous cell carcinoma & 1 & 54 & N131fs*13 & 1.85 \\
\hline Large intestine-cecum adenocarcinoma & 2 & 125 & V85fs*46, R253Q & 1.60 \\
\hline Soft tissue-rhabdomyosarcoma & 1 & 81 & N183S & 1.21 \\
\hline Stomach-intestinal adenocarcinoma & 1 & 85 & T356M & 1.18 \\
\hline Urinary tract-bladder transitional cell carcinoma & 1 & 114 & H50Q & 0.88 \\
\hline Large intestine-adenocarcinoma & 3 & 384 & G35E,R76G,L285P & 0.78 \\
\hline Endometrium-endometrioid carcinoma & 4 & 548 & $\begin{array}{l}\text { R180Q,R197Q, Q276P, } \\
\text { R375C }\end{array}$ & 0.73 \\
\hline Large intestine-colon adenocarcinoma & 4 & 715 & $\begin{array}{l}\text { P40S,R197W,R310H, } \\
\text { G344C }\end{array}$ & 0.70 \\
\hline Liver-neoplasm & 1 & 162 & A18D & 0.62 \\
\hline $\begin{array}{l}\text { Upper aerodigestive tract-mouth squamous cell } \\
\text { carcinoma }\end{array}$ & 1 & 221 & L136P & 0.45 \\
\hline Liver-hepatocellular carcinoma & 4 & 921 & $\begin{array}{l}\text { T376K,R375C,G344D, } \\
\text { V329F }\end{array}$ & 0.43 \\
\hline Skin-malignant melanoma & 3 & 818 & W82R, L202F, P371L & 0.37 \\
\hline Urinary tract-bladder carcinoma & 2 & 554 & H50Q,D205N & 0.36 \\
\hline Lung-squamous cell carcinoma & 2 & 655 & L133F,E282*stop & 0.31 \\
\hline Kidney-papillary renal cell carcinoma & 1 & 335 & $\mathrm{R} 375 \mathrm{H}$ & 0.30 \\
\hline Liver-carcinoma & 1 & 725 & F378L & 0.14 \\
\hline Lung-adenocarcinoma & 1 & 772 & $\mathrm{~S} 4 \mathrm{C}$ & 0.13 \\
\hline Kidney-clear cell renal cell carcinoma & 1 & 865 & $\mathrm{H} 74 \mathrm{Y}$ & 0.12 \\
\hline Breast-carcinoma & 1 & 1263 & $\mathrm{D} 210 \mathrm{~N}$ & 0.08 \\
\hline
\end{tabular}

Data were extracted from the COSMIC database (The Catalogue of Somatic Mutations in Cancer) [56, 57]

${ }^{a}$ These two mutations were found in the same sample

had a less severe disease penetration than patients with the de novo V155M mutation [38, 39, 42]. Jeremiah et al. [39], first found that the V155M mutation, at the steady state, localized mainly in the Golgi and in perinuclear vesicles of patient fibroblasts, which is a hallmark of the STING activation.

\section{SAVI as a unique interferonopathy with lung manifestation}

SAVI is considered as a type I Interferonopathy that includes chronic atypical neutrophilic dermatosis with lipodystrophy and elevated temperature, Aicardi-Goutieres syndrome, and TREX1-SAMHD1-mediated familial chilblain lupus [40, 43, 44]. For example, familial SAVI mutations caused familial chilblain lupus [39, 41]. However, SAVI is unique because it is the only known type I
Interferonopathy with pulmonary involvement [40, 43, 44]. In fact, all three reported fatalities from SAVI patients were due to the pulmonary complications [38, 40]. We showed that activating STING in the mouse lung by intranasal administration of CDNs, induced lung production of IFN $\gamma$ and IFN $\lambda$ but not IFN $\beta$ [45]. Interestingly, IFN $\gamma^{+} \mathrm{CD}^{+}$ $\mathrm{T}$ cells and serum IFN $\gamma$ were markedly increased in a recent SAVI patient [46]. Notably, serum IL-18, a known IFN $\gamma$ inducer, was also elevated in several SAVI patients [47]. Whether the increased IFN $\gamma$ production contributes to the lung symptoms in SAVI patients is worth further investigation.

\section{Treating SAVI with JAK inhibitors}

Current anti-inflammatory treatments corticosteroid, DMARDs, anti-TNF, steroids, anti-CD20, IVIG, were 
ineffective in SAVI patients [42, 47]. SAVI patients died of lung complication, and lung damage was irreversible [40, 47]. In fact, one SAVI patient died after double lung transplantation due to acute complications [40]. Thus, any SAVI treatment should result in improved lung function and prevent the irreversible lung damage.

Encouragingly, in a 2-year study with three SAVI children, ruxolitinib dramatically improved pulmonary function, resolved the cutaneous lesions and led to a better overall well-being of the patients [42, 48]. In a separate study, after a 3-month tofacitinib treatment, Seo et al. [46], saw an improved skin lesion in a SAVI teenager but the pulmonary defect remained. Eli Lilly is currently conducting a clinical trial (ClinicalTrials.gov number, NCT01724580) to examine the efficacy of baricitinib in SAVI patients.

Ruxolitinib and baricitinib are JAK1 and JAK2 inhibitors while tofacitinib is a JAK3 and to a lesser degree, JAK2 inhibitor. IFN $\alpha / \beta$ signals via JAK1/Tyk 2 while IFN $\gamma$ activates JAK1/JAK2. Thus, ruxolitinib and baricitinib are more suitable for treating SAVI than tofacitinib. Notably, baricitinib, at a high dose, also inhibits Tyk2, which mediates IL-10, IL-12/23, IL-6, and IL-4/13 signaling. Proper dosing may be important when treating SAVI patients with baricitinib.

\section{Loss-of-function human TMEM173 allele as a natural inhibitor of SAVI}

SAVI is caused by gain-of-function human TMEM173 mutations [38] (Table 1). An intriguing question is whether the loss-of-function TMEM173 alleles could serve as natural genetic inhibitors [49]. Cerboni et al. [49] found that in vitro, introducing $H A Q$ into the V155M SAVI mutation (HAQ-V155M) relocated STING back to ER, restored T cell proliferation, and corrected $\mathrm{NF}-\kappa \mathrm{B}$ activation . Recently, a de novo SAVI patient was identified in a $H A Q$ family [46]. In this case, the activating TMEM173 mutation acts in trans with the $H A Q$ allele [46]. The patient exhibited SAVI symptoms but with a late-onset (3 years) [46]. Thus, the presence of the $H A Q$ allele could be advantageous to SAVI patients.

\section{TMEM173 mutations in human cancers}

STING can promote [50, 51] or suppress [52, 53] tumorigenesis in mice. Xia et al., sequenced the TMEM173 gene in 11 human colon cancer cell lines and 11 human melanoma-derived cell lines [54, 55]. No somatic TMEM173 mutations were found, although 2 out of the 11 colon cancer lines and 7 out of the 11 melanoma lines carried the $H A Q$ allele $[54,55]$. Data from the COSMIC
(The Catalogue of Somatic Mutations in Cancer) confirmed that somatic human TMEM173 mutation is rare in cancers [56, 57]. Out of 30,710 primary human cancer samples, only 43 samples have somatic TMEM173 mutations, a mutation rate of $0.11 \%[56,57]$ (Table 2).

Among the somatic human TMEM173 mutations identified (Table 2), R284M is an activating TMEM173 mutation [58]. This mutation was found in a lung-right lower lobe adenocarcinoma (Table 2) [56]. Interestingly, a similar TMEM173-activating mutant, R284G, was recently found in a SAVI patient [59]. This patient had recurrent bacterial infections in the upper respiratory tract but never had systemic markers of inflammation [59]. Her lung function was also normal [59]. Thus, the activating R284M mutation in the lung cancer sample is likely not causative. In conclusion, somatic TMEM173 gene mutation is rare in human cancers and does not seem to play a major role in tumorigenesis.

\section{TMEM173 gene expression in human cancers}

Decreased STING expression was observed in some human melanoma cell lines and tissues [55, 60]. In COSMIC database, however, out of 9110 primary human cancer tissues, 313 samples $(3.44 \%)$ have overexpressed TMEM173 gene expression $(Z$-score $>2)$ compared to the 17 samples $(0.19 \%)$ that have underexpressed TMEM173 gene (Z-score $<-2)$ [56, 57]. Samples from lung cancers, brain cancers, and kidney cancers have the highest rate of TMEM173 gene overexpression [56, 57].

Why do cancer samples have overexpressed TMEM173 gene? The vast majority of those cancer samples did not have somatic TMEM173 mutations. Wang et al. [61], recently reported that c-Myc binds to the -124 to $1 \mathrm{bp}$ of the human TMEM173 gene and promotes its transcription. c-Myc is activated in many cancers. It is tempting to suggest that TMEM173 overexpression in human cancer samples is driven by the activated c-Myc. Whether the overexpressed TMEM173 gene in human cancer samples contributes to tumorigenesis, remains to be determined.

\section{TMEM173 alleles in human medicine}

STING is a promising therapeutic target for cancer immunotherapies [16-18, 62]. Pneumovax $23^{\circledR}$ vaccine efficacy depends on STING in mice [26, 63]. STING may also contribute to the efficacy of the radiotherapy [16] and chemotherapy [55, 64] likely due to DNA released during these treatments. Using a mouse model of the human $H A Q$ allele, we found that Pneumovax $23^{\circledR}$ was ineffective in the HAQ mouse [26]. Furthermore, CDNs lost its adjuvant 
activity in the HAQ mouse [26]. The low expression of STING in the $H A Q / H A Q$ individuals likely will affect the efficacy of STING-targeting cancer immunotherapies.

On the other hand, increased STING expression in primary human cancer samples provides a rationale for targeting STING for cancer treatments. STING/MPYS was initially identified as an apoptotic molecule mediating antiMHC II mAb induced cell death in mouse B-cell lymphomas [21]. Recently, several studies showed that direct activation of STING by CDNs could kill tumors [65, 66]. Thus, tumors with increased STING expression may be killed directly by the activation of STING/MPYS-mediated cell death pathway. On the other hand, activation of the STING pathway in DCs promotes DCs maturation [67, 68]. These mature DCs can initiate $\mathrm{CD}^{+} \mathrm{T}$ cells-mediated cytotoxic response and generate memory response to prevent cancer relapse [17, 18, 69-73].

\section{Future directions}

Since its discovery in 2008, most of our knowledge on STING has been from mouse studies. These studies have established a critical role of STING in infectious diseases and autoimmune diseases. The identification of SAVI mutations in 2014 established an unambiguous role of the TMEM173 gene in the human auto-inflammatory disease. However, the role of TMEM173 in human infectious diseases remains to be determined. A recent study done in two independent European cohorts (150 patients and 188 controls) found that the population frequency of $H A Q$ increased in human Legionnaires' disease patients as compared to healthy controls, which suggested that $H A Q$ carriers may be more susceptible to Legionnaires' disease than the $R 232$ carriers [74]. Questions remain whether $H A Q$ affects individual's susceptibility/resistance to other human pathogens such as HIV, Plasmodium, or Mycobacterial tuberculosis. Meanwhile, a GWAS study revealed an association between the TMEM173 gene and ESCC [37]. It remains to be determined whether the $H A Q$ and $H 232$ alleles associated with ESCC are causative, which will greatly enhance the mechanistic understanding of this disease.

The animal and in vitro studies indicated that STING might influence the efficacy of some human medicines [16, 26, 64]. It will be beneficial to determine whether the $H A Q$ and $H 232$ alleles cause decreased efficacy for Pneumovax $23^{\circledR}$, chemotherapy, and radiotherapy so that right patients can be benefited from these medications.

Lastly, the $H A Q$ allele is common in East Asians and rare in Africans [26]. The $H 232$ allele, however, does not show such population stratification [26]. Thus, the environmental pressure selecting for the $H A Q$ allele seems to be different from the $H 232$ allele. Determining the environmental factor (s) selecting for these loss-of-function TMEM173 alleles will help us understand the physiological function of the human TMEM173 gene.

Funding This work was supported by NIH grants AI110606 and AI125999 (to LJ) and a new faculty start-up fund from University of Florida, Department of Medicine (to LJ).

\section{Compliance with ethical standards}

Conflict of interest The authors declare that they have no conflict of interest.

Open Access This article is licensed under a Creative Commons Attribution 4.0 International License, which permits use, sharing, adaptation, distribution and reproduction in any medium or format, as long as you give appropriate credit to the original author(s) and the source, provide a link to the Creative Commons license, and indicate if changes were made. The images or other third party material in this article are included in the article's Creative Commons license, unless indicated otherwise in a credit line to the material. If material is not included in the article's Creative Commons license and your intended use is not permitted by statutory regulation or exceeds the permitted use, you will need to obtain permission directly from the copyright holder. To view a copy of this license, visit http://creativecommons. org/licenses/by/4.0/.

\section{References}

1. Ishikawa H, Barber GN. STING is an endoplasmic reticulum adaptor that facilitates innate immune signalling. Nature. 2008;455:674-8.

2. Zhong B, Yang Y, Li S, Wang YY, Li Y, Diao F, et al. The adaptor protein MITA links virus-sensing receptors to IRF3 transcription factor activation. Immunity. 2008;29:538-50.

3. Ouyang S, Song X, Wang Y, Ru H, Shaw N, Jiang Y, et al. Structural analysis of the STING adaptor protein reveals a hydrophobic dimer interface and mode of cyclic di-GMP binding. Immunity. 2012;36:1073-86.

4. Gao P, Ascano M, Zillinger T, Wang W, Dai P, Serganov AA, et al. Structure-function analysis of STING activation by c[G $\left.\left(2^{\prime}, 5^{\prime}\right) \mathrm{pA}\left(3^{\prime}, 5^{\prime}\right) \mathrm{p}\right]$ and targeting by antiviral DMXAA. Cell. 2013;154:748-62.

5. Yin Q, Tian Y, Kabaleeswaran V, Jiang X, Tu D, Eck MJ, et al. Cyclic di-GMP sensing via the innate immune signaling protein STING. Mol Cell. 2012;46:735-45.

6. Jakobsen MR, Bak RO, Andersen A, Berg RK, Jensen SB, Tengchuan J, et al. IFI16 senses DNA forms of the lentiviral replication cycle and controls HIV-1 replication. Proc Natl Acad Sci USA. 2013;110:E4571-80.

7. Gao D, Wu J, Wu YT, Du F, Aroh C, Yan N, et al. Cyclic GMPAMP synthase is an innate immune sensor of HIV and other retroviruses. Science. 2013;341:903-6.

8. Yu X, Cai B, Wang M, Tan P, Ding X, Wu J, et al. Crossregulation of two type I interferon signaling pathways in plasmacytoid dendritic cells controls anti-malaria immunity and host mortality. Immunity. 2016;45:1093-107.

9. Spaulding E, Fooksman D, Moore JM, Saidi A, Feintuch CM, Reizis B, et al. STING-licensed macrophages prime type I IFN production by plasmacytoid dendritic cells in the bone marrow during severe Plasmodium yoelii malaria. PLoS Pathog. 2016;12: e1005975. 
10. Sharma S, DeOliveira RB, Kalantari P, Parroche P, Goutagny N, Jiang $\mathrm{Z}$, et al. Innate immune recognition of an AT-rich stem-loop DNA motif in the Plasmodium falciparum genome. Immunity. 2011;35:194-207.

11. Watson RO, Manzanillo PS, Cox JS. Extracellular M. tuberculosis DNA targets bacteria for autophagy by activating the host DNAsensing pathway. Cell. 2012;150:803-15.

12. Watson RO, Bell SL, MacDuff DA, Kimmey JM, Diner EJ, Olivas J, et al. The cytosolic sensor cGAS detects Mycobacterium tuberculosis DNA to induce type I interferons and activate autophagy. Cell Host Microbe. 2015;17:811-9.

13. Collins AC, Cai H, Li T, Franco LH, Li XD, Nair VR, et al. Cyclic GMP-AMP synthase is an innate immune DNA sensor for Mycobacterium tuberculosis. Cell Host Microbe. 2015;17:820-8.

14. Gall A, Treuting P, Elkon KB, Loo YM, Gale M Jr, Barber GN, et al. Autoimmunity initiates in nonhematopoietic cells and progresses via lymphocytes in an interferon-dependent autoimmune disease. Immunity. 2012;36:120-31.

15. Sharma S, Campbell AM, Chan J, Schattgen SA, Orlowski GM, Nayar R, et al. Suppression of systemic autoimmunity by the innate immune adaptor STING. Proc Natl Acad Sci USA. 2015;112:E710-7.

16. Deng L, Liang H, Xu M, Yang X, Burnette B, Arina A, et al. STING-dependent cytosolic DNA sensing promotes radiationinduced type I interferon-dependent antitumor immunity in immunogenic tumors. Immunity. 2014;41:843-52.

17. Woo SR, Fuertes MB, Corrales L, Spranger S, Furdyna MJ, Leung MY, et al. STING-dependent cytosolic DNA sensing mediates innate immune recognition of immunogenic tumors. Immunity. 2014;41:830-42.

18. Fu J, Kanne DB, Leong M, Glickman LH, McWhirter SM, Lemmens E, et al. STING agonist formulated cancer vaccines can cure established tumors resistant to PD-1 blockade. Sci Transl Med. 2015;7:283ra252.

19. Crowl JT, Gray EE, Pestal K, Volkman HE, Stetson DB. Intracellular nucleic acid detection in autoimmunity. Annu Rev Immunol. 2017;35:313-36.

20. Kato K, Omura H, Ishitani R, Nureki O. Cyclic GMP-AMP as an endogenous second messenger in innate immune signaling by cytosolic DNA. Annu Rev Biochem. 2017;86:541-66.

21. Jin L, Waterman PM, Jonscher KR, Short CM, Reisdorph NA, Cambier JC. MPYS, a novel membrane tetraspanner, is associated with major histocompatibility complex class II and mediates transduction of apoptotic signals. Mol Cell Biol. 2008;28:5014-26.

22. Jin L, Xu LG, Yang IV, Davidson EJ, Schwartz DA, Wurfel MM, et al. Identification and characterization of a loss-of-function human MPYS variant. Genes Immun. 2011;12:263-9.

23. Zhang X, Shi H, Wu J, Zhang X, Sun L, Chen C, et al. Cyclic GMP-AMP containing mixed phosphodiester linkages is an endogenous high-affinity ligand for STING. Mol Cell. 2013;51:226-35.

24. Burdette DL, Monroe KM, Sotelo-Troha K, Iwig JS, Eckert B, Hyodo M, et al. STING is a direct innate immune sensor of cyclic di-GMP. Nature. 2011;478:515-8.

25. Yi G, Brendel VP, Shu C, Li P, Palanathan S, Cheng Kao C. Single nucleotide polymorphisms of human STING can affect innate immune response to cyclic dinucleotides. PLoS ONE. 2013;8:e77846.

26. Patel S, Blaauboer SM, Tucker HR, Mansouri S, Ruiz-Moreno JS, Hamann L, et al. The common R71H-G230A-R293Q human TMEM173 is a null allele. J Immunol. 2017;198:776-87.

27. Patel S, Blaauboer SM, Tucker HR, Mansouri S, Ruiz-Moreno JS, Hamann L, et al. Response to comment on "The Common R71HG230A-R293Q Human TMEM173 Is a Null Allele". J Immunol. 2017;198:4185-8.
28. Kennedy RB, Ovsyannikova IG, Pankratz VS, Haralambieva IH, Vierkant RA, Poland GA. Genome-wide analysis of polymorphisms associated with cytokine responses in smallpox vaccine recipients. Hum Genet. 2012;131:1403-21.

29. Sivick KE, Surh NH, Desbien AL, Grewal EP, Katibah GE, McWhirter SM, et al. Comment on "The Common R71H-G230AR293Q Human TMEM173 Is a Null Allele”. J Immunol. 2017;198:4183-5.

30. Chen Q, Sun L, Chen ZJ. Regulation and function of the cGASSTING pathway of cytosolic DNA sensing. Nat Immunol. 2016;17:1142-9.

31. Enard D, Cai L, Gwennap C, Petrov DA. Viruses are a dominant driver of protein adaptation in mammals. eLife. 2016;5:e12469.

32. Xu F, Sternberg MR, Kottiri BJ, McQuillan GM, Lee FK, Nahmias AJ, et al. Trends in herpes simplex virus type 1 and type 2 seroprevalence in the United States. JAMA. 2006;296:964-73.

33. Menendez CM, Carr DJJ. Defining nervous system susceptibility during acute and latent herpes simplex virus-1 infection. J Neuroimmunol. 2017;308:43-49.

34. Ishikawa $\mathrm{H}$, Ma Z, Barber GN. STING regulates intracellular DNA-mediated, type I interferon-dependent innate immunity. Nature. 2009;461:788-92.

35. Parker ZM, Murphy AA, Leib DA. Role of the DNA sensor STING in protection from lethal infection following corneal and intracerebral challenge with herpes simplex virus 1 . J Virol. 2015;89:11080-91.

36. Royer DJ, Carr DJ. A STING-dependent innate-sensing pathway mediates resistance to corneal HSV-1 infection via upregulation of the antiviral effector tetherin. Mucosal Immunol. 2016;9:1065-75.

37. Wu C, Wang Z, Song X, Feng XS, Abnet CC, He J, et al. Joint analysis of three genome-wide association studies of esophageal squamous cell carcinoma in Chinese populations. Nat Genet. 2014;46:1001-6.

38. Liu Y, Jesus AA, Marrero B, Yang D, Ramsey SE, Sanchez GAM, et al. Activated STING in a vascular and pulmonary syndrome. N Engl J Med. 2014;371:507-18.

39. Jeremiah N, Neven B, Gentili M, Callebaut I, Maschalidi S, Stolzenberg $\mathrm{MC}$, et al. Inherited STING-activating mutation underlies a familial inflammatory syndrome with lupus-like manifestations. J Clin Invest. 2014;124:5516-20.

40. Picard C, Thouvenin G, Kannengiesser C, Dubus JC, Jeremiah N, Rieux-Laucat F, et al. Severe pulmonary fibrosis as the first manifestation of interferonopathy (TMEM173 mutation). Chest. 2016;150:e65-71.

41. Konig N, Fiehn C, Wolf C, Schuster M, Cura Costa E, Tungler V, et al. Familial chilblain lupus due to a gain-of-function mutation in STING. Ann Rheum Dis. 2017;76:468-72.

42. Fremond ML, Rodero MP, Jeremiah N, Belot A, Jeziorski E, Duffy D, et al. Efficacy of the Janus kinase 1/2 inhibitor ruxolitinib in the treatment of vasculopathy associated with TMEM173-activating mutations in 3 children. J Allergy Clin Immunol. 2016;138:1752-5.

43. Volpi S, Picco P, Caorsi R, Candotti F, Gattorno M. Type I interferonopathies in pediatric rheumatology. Pediatr Rheumatol Online J. 2016;14:35.

44. Munoz J, Rodiere M, Jeremiah N, Rieux-Laucat F, Oojageer A, Rice GI, et al. Stimulator of interferon genes-associated vasculopathy with onset in infancy: a mimic of childhood granulomatosis with polyangiitis. JAMA Dermatol. 2015;151:872-7.

45. Blaauboer SM, Mansouri S, Tucker HR, Wang HL, Gabrielle VD, Jin L. The mucosal adjuvant cyclic di-GMP enhances antigen uptake and selectively activates pinocytosis-efficient cells in vivo. Elife. 2015;4:e6670.

46. Seo J, Kang JA, Suh DI, Park EB, Lee CR, Choi SA, et al. Tofacitinib relieves symptoms of stimulator of interferon genes (STING)-associated vasculopathy with onset in infancy caused by 
2 de novo variants in TMEM173. J Allergy Clin Immunol. 2017;139:1396-9.e1312.

47. Liu Y, Li J, Chen J, Li Y, Wang W, Du X, et al. Hepatitis B virus polymerase disrupts K63-linked ubiquitination of STING to block innate cytosolic DNA-sensing pathways. J Virol. 2015;89:2287-300.

48. Rodero MP, Fremond ML, Rice GI, Neven B, Crow YJ. JAK inhibition in STING-associated interferonopathy. Ann Rheum Dis. 2016;75:e75.

49. Cerboni S, Jeremiah N, Gentili M, Gehrmann U, Conrad C, Stolzenberg MC, et al. Intrinsic antiproliferative activity of the innate sensor STING in $\mathrm{T}$ lymphocytes. J Exp Med. 2017;214:1769-85.

50. Ahn J, Xia T, Konno H, Konno K, Ruiz P, Barber GN. Inflammation-driven carcinogenesis is mediated through STING. Nat Commun. 2014;5:5166.

51. Lemos H, Mohamed E, Huang L, Ou R, Pacholczyk G, Arbab AS, et al. STING promotes the growth of tumors characterized by low antigenicity via IDO activation. Cancer Res. 2016;76:2076-81.

52. Ahn J, Konno H, Barber GN. Diverse roles of STING-dependent signaling on the development of cancer. Oncogene. 2015;34:5302-8.

53. Zhu Q, Man SM, Gurung P, Liu Z, Vogel P, Lamkanfi M, et al. Cutting edge: STING mediates protection against colorectal tumorigenesis by governing the magnitude of intestinal inflammation. J Immunol. 2014;193:4779-82.

54. Xia T, Konno H, Ahn J, Barber GN. Deregulation of STING signaling in colorectal carcinoma constrains DNA damage responses and correlates with tumorigenesis. Cell Rep. 2016;14:282-97.

55. Xia T, Konno H, Barber GN. Recurrent loss of STING signaling in melanoma correlates with susceptibility to viral oncolysis. Cancer Res. 2016;76:6747-59.

56. Forbes SA, Beare D, Boutselakis H, Bamford S, Bindal N, Tate J, et al. COSMIC: somatic cancer genetics at high-resolution. Nucleic Acids Res. 2017;45:D777-83.

57. Forbes SA, Beare D, Bindal N, Bamford S, Ward S, Cole CG, et al. COSMIC: high-resolution cancer genetics using the catalogue of somatic mutations in cancer. Curr Protoc Hum Genet. 2016;91:1-10.

58. Tang ED, Wang CY. Single amino acid change in STING leads to constitutive active signaling. PLoS ONE. 2015;10:e0120090.

59. Melki I, Rose Y, Uggenti C, Van Eyck L, Fremond ML, Kitabayashi N, et al. Disease-associated mutations identify a novel region in human STING necessary for the control of type I interferon signaling. J Allergy Clin Immunol. 2017;140:543-52. e545.

60. Song S, Peng P, Tang Z, Zhao J, Wu W, Li H, et al. Decreased expression of STING predicts poor prognosis in patients with gastric cancer. Sci Rep. 2017;7:39858.

61. Wang YY, Jin R, Zhou GP, Xu HG. Mechanisms of transcriptional activation of the stimulator of interferon genes by transcription factors CREB and c-Myc. Oncotarget. 2016;7:85049-57.
62. Corrales L, Glickman LH, McWhirter SM, Kanne DB, Sivick KE, Katibah GE, et al. Direct activation of STING in the tumor microenvironment leads to potent and systemic tumor regression and immunity. Cell Rep. 2015;11:1018-30.

63. Zeng M, Hu Z, Shi X, Li X, Zhan X, Li XD, et al. MAVS, cGAS, and endogenous retroviruses in $\mathrm{T}$-independent $\mathrm{B}$ cell responses. Science. 2014;346:1486-92.

64. Gaston J, Cheradame L, Yvonnet V, Deas O, Poupon MF, Judde $\mathrm{JG}$, et al. Intracellular STING inactivation sensitizes breast cancer cells to genotoxic agents. Oncotarget. 2016;7:77205-24.

65. Tang $\mathrm{CH}$, Zundell JA, Ranatunga S, Lin C, Nefedova Y, Del Valle JR, et al. Agonist-Mediated Activation of STING Induces Apoptosis in Malignant B Cells. Cancer Res. 2016;76:2137-52.

66. Gulen MF, Koch U, Haag SM, Schuler F, Apetoh L, Villunger A, et al. Signalling strength determines proapoptotic functions of STING. Nat Commun. 2017;8:427.

67. Karaolis DK, Means TK, Yang D, Takahashi M, Yoshimura T, Muraille E, et al. Bacterial c-di-GMP is an immunostimulatory molecule. J Immunol. 2007;178:2171-81.

68. Blaauboer SM, Gabrielle VD, Jin L. MPYS/STING-mediated TNF-alpha, not type I IFN, is essential for the mucosal adjuvant activity of (3'-5')-cyclic-di-guanosine-monophosphate in vivo. J Immunol. 2014;192:492-502.

69. Ager CR, Reilley MJ, Nicholas C, Bartkowiak T, Jaiswal AR, Curran MA. Intratumoral STING activation with T cell checkpoint modulation generates systemic antitumor immunity. Cancer Immunol Res. 2017;5:676-84.

70. Chandra D, Quispe-Tintaya W, Jahangir A, Asafu-Adjei D, Ramos I, Sintim HO, et al. STING ligand c-di-GMP improves cancer vaccination against metastatic breast cancer. Cancer Immunol Res. 2014;2:901-10.

71. Ohkuri T, Ghosh A, Kosaka A, Zhu J, Ikeura M, David M, et al. STING contributes to antiglioma immunity via triggering type I IFN signals in the tumor microenvironment. Cancer Immunol Res. 2014;2:1199-208.

72. Smith TT, Moffett HF, Stephan SB, Opel CF, Dumigan AG, Jiang $\mathrm{X}$, et al. Biopolymers codelivering engineered $\mathrm{T}$ cells and STING agonists can eliminate heterogeneous tumors. J Clin Invest. 2017;127:2176-91.

73. Wang Z, Celis E. STING activator c-di-GMP enhances the antitumor effects of peptide vaccines in melanoma-bearing mice. Cancer Immunol Immunother. 2015;64:1057-66.

74. Ruiz-Moreno JS, Hamann L, Shah JA, Verbon A, Mockenhaupt FP, Puzianowska-Kuznicka M, et al. The common HAQ STING variant impairs cGAS-dependent antibacterial responses and is associated with susceptibility to Legionnaires' disease in humans. PLoS Pathog. 2018;14:e1006829.

75. Tanaka Y, Chen ZJ. STING specifies IRF3 phosphorylation by TBK1 in the cytosolic DNA signaling pathway. Sci Signal. 2012;5:ra20.

76. Liu S, Cai X, Wu J, Cong Q, Chen X, Li T, et al. Phosphorylation of innate immune adaptor proteins MAVS, STING, and TRIF induces IRF3 activation. Science. 2015;347:aaa2630. 